Myco. phlei and four other strains of saprophytic acid-fast bacilli were injected in doses of $10^{-2}$ to $10^{-4} \mathrm{mgm}$. With the larger doses, smears from the inoculum revealed many acid-fast bacilli and these were, of course, detected in mice two weeks later. After four weeks there were, however, slightly fewer bacilli. With doses of $10^{-4} \mathrm{mgm}$. very few bacilli were seen at all; the results were therefore very different from those obtained with virulent tubercle bacilli.

In this work three sepcrate laboratory strains of white mice, maintained on stock diets, have all been equally susceptible. Mice varying in age from three weeks to 'adult' were used, and although the young mice appeared to be slightly more susceptible, the difference was considered to be unimportant.

No evidence has been obtained to conflict with the view that it is difficult to produce generalized. tuberculosis in mice following subcutaneous infection; but the foregoing results indicate that, if smears are made from the site of inoculation, it may be possible to use mice for the routine detection of small numbers of virulent tubercle bacilli. The method is now being tried on clinical material.

Dopartment of Preventive Medicine, JoHN Francis Veterinary School, University of Queensland, Brisbane.

Oct. 28.

${ }^{1}$ Cobbett, I., "The Causes of Tuberculosis" (Cambridge, 1917). 2 Stewart, G. T., Brit. J. Exp. Path., 31, 5 (1950). Pierce, C., Dubos, R. J and Schaefer, W. B, J.Exp. Med, 97, 189 (1953). ${ }^{3}$ Glover, R. E., Brit. J. Exp. Path., 25, 141 (1944).

- Gray, D. F., and Mattinson, M. W., Amer. Rev. Tuberc., 65. 572 (1952). Gray, D F., Clarke, B. L., and Mattinson, M. W., Amer. Rev. Tuberc., 69, 92 (1954).

\section{Larva of Sphaerophoria as Predators on Thrips in South Africa}

IN an earlier paper ${ }^{1}$ attention was directed to the fact that thrips have remarkably fow effective natural enemies. Syrphidae were mentioned $\mathrm{css}$ predators; but the thrips-feeding habit seems to be very rare in these insects, the larvæ of most of the entomophagous forms feeding on aphids and other Homoptera. Some Syrphid larvæ, however, are known to prey on other insects, such as caterpillars ; but there seem to be scarcely any records of species feeding on thrips. Where thrips are rather inactive and congregated in numbers on leaves or in galls, they would seem to be more liable to attack by predators such as Syrphid larvæ.

At Grahamstown, Cape Province, South Africa, larvæ of the Syrphid fly, Sphaerophoria quadrituberculata Bezzi (Diptera, Syrphidae), were observed feeding on the immature stages of the thrips, Cercothrips afer Priesner, in curled leaves of a plant originally thought to be Ficus burtt-davyi Hutch., but now identified as Ficus craterostoma Warburg. All the Syrphid larvæ found were in the third or final instar, and were nearly fully grown. They were kept in glass dishes in the laboratory and supplied with thrips several times a day. The thrips larvæ, prepupæ and pupæ were eaten voraciously, the Syrphid larvæ striking out vigorously in all directions until contact was established with the prey; but the adult thrips were not attacked. This appears to be the first record in Africa of the thrips-feeding habit in Syrphidae. Prof. J. C. Faure, Dr. E. K. Hartwig and Mr. J. C. Jacot-Guillarmod kindly inform me (in litt., 1954) that they have never observed or know of any records of Syrphid larvæ feeding on thrips in South Africa.

Cercothrips afer is large for a thrips and is a most conspicuous species. The immature stages are bright red, whereas the adults are black and attain a length of $7 \mathrm{~mm}$. Although this thrips may occur in considerable numbers in the curled leaves of $F$. craterostoma, it lives there as an inquiline, and is not in any way responsible for the curling. Actually the curling of the leaves results from the feeding activities of another and smaller thrips, Gynaikothrips hirsutus (Karny). This thrips, too, is often very numerous in such curled leaves, which can really be termed open galls, for the inward rolling of the edges of the leaves is accompanied by marked hypertrophy of the plant tissue. Both thrips have been recorded previously from South Africa. Jacot-Guillarmod ${ }^{2}$ found Cercothrips associated with Gynaikothrips on Ficus petersii Warburg in Natal ; but, although he suggested the curling of the leaves was probably due to the latter species, he did not state definitely that Cercothrips lives as an inquiline in the curled leaves. My observations leave no doubt as to the respective parts played by the two species of thrips.

Although the Syrphidae include some of the most important of beneficial insects, they have as yet been little studied in Africa. As in other parts of the world, however, the larvæ of the entomophagous species will probably be found to be mainly aphidophagous. The genus Sphaerophoria is world-wide in distribution, and its larvæ are known to be predators on aphids and other homopterous insects. Only two species of Sphaerophoria appear to have been recorded so far from the Ethiopian region. Sphaerophoria quadrituberculata is a remarkable species. It was deseribed by Bezzi ${ }^{3}$ in 1915 from Durban, Natal, but does not seem to have been found since. The males are unusual in having a pair of large, conspicuous, raised tubercles on both the third and fourth tergites of the abdomen, to which the specific name directs attention. The structure of the immature stages, described recently by Stuckenberg 4 , is equally remarkable, and the thrips-feeding habit of the larvæ is exceptional. The feeding habits of this species were hitherto unknown. Curled leaves present a highly specialized environment, and it would be interesting to know if the larvæ of this Syrphid occur in habitats other than galls and prey on insects other than thrips. It seems not unlikely, however, that the larvæ of this species are restricted to this ecological niche in curled leaves and feed exclusively on thrips.

I am grateful to Mr. C. F. Jacot-Guillarmod for naming the two species of thrips, and to Dr. L. E. W. Codd for the identification of Ficus craterostoma. Mr. B. R. Stuckenberg kindly identified the Syrphid and described its immature stages, which were previously unknown.

\section{E. MoC. Callan}

Department of Zoology and Entomology, Rhodes University, Grahamstown, South Africa. Sept. 7.

x Callan, E. MeC., Bull. Ent. Res., 34, 313 (1943).

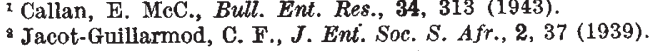

3 Bezzi, M., Brit. Mus. Pub., 35 (1915).

- Stuckenberg, B. R., J. Ent. Soc. S. Afr., 17, 58 (1954). 